DOI 10.22460/infinity.v6i1.243

\title{
SENIOR HIGH SCHOOL TEACHERS' MATHEMATICAL QUESTIONING ABILITY AND METAPHORICAL THINKING LEARNING
}

\author{
Heris Hendriana \\ Mathematics Education, STKIP Siliwangi, Cimahi, Indonesia \\ herishen@yahoo.com
}

Received: October 30, 2016 ; Accepted: January 28, 2017

\begin{abstract}
This study is designed in the form of experiment with the design of control group and posttest only aimed at investigating the role of learning that teaches metaphorical thinking in improving senior high school teachers' mathematical questioning ability. The population of this study was senior high school teachers of mathematics in West Java province and the samples were 124 senior high school teachers of mathematics set purposively and randomly to be included into the experimental class and control class. Based on the results and discussion, it is concluded that: (1) mathematical questioning ability of the teachers who received metaphorical thinking learning is better than those who received conventional learning; (2) learning factors and KAM (Kemampuan Awal Matematis = Prior Mathematical Ability) affect the achievement of teachers' mathematical questioning ability. In addition, there is an interaction effect between the learning and KAM in developing teachers' mathematical questioning ability; (3) teachers' mathematical questioning ability has not been achieved optimally on the indicators submitting problems in the form of non-routine questions and open-ended questions.
\end{abstract}

Keywords: KAM, Mathematical Questioning Ability, Metaphorical Thinking

\begin{abstract}
Abstrak
Studi ini dirancang dalam bentuk eksperimen dengan disain kelompok kontrol dan postes saja yang bertujuan menelaah peranan pembelajaran yang mengajarkan berpikir metaforik terhadap kemampuan bertanya matematis guru SMA. Populasi dalam penelitian ini adalah guru SMA mata pelajaran matematika di Provinsi Jawa Barat, sedangkan sampel penelitian ini adalah 124 orang guru SMA mata pelajaran matematika yang ditetapkan secara purposif kemudian ditetapkan secara acak yang termasuk ke dalam kelas eksperimen dan kelas kontrol. Berdasarkan hasil dan pembahasan diperoleh kesimpulan: (1) Kemampuan bertanya matematis guru yang memperoleh pembelajaran Metaphorical Thinking lebih baik daripada yang memperoleh pembelajaran biasa; (2) Faktor pembelajaran dan KAM masing-masing mempengaruhi ketercapaian kemampuan bertanya matematis guru. Selain itu, terdapat efek interaksi antara pembelajaran dan KAM secara bersama-sama dalam mengembangkan kemampuan bertanya matematis guru; (3) Ketercapaian penguasaan kemampuan bertanya matematis guru masih belum tercapai dengan baik pada indikator pengajuan permasalahan berupa pertanyaan non-rutin dan pertanyaan terbuka.
\end{abstract}

Kata Kunci: KAM, Kemampuan Bertanya Matematis, Metaphorical Thinking

How to Cite: Hendriana, H. (2017). Senior High School Teachers' Mathematical Questioning Ability and Metaphorical Thinking Learning. Infinity, 6 (1), 51-58. 


\section{INTRODUCTION}

Conversations in daily life can be done both in formal and informal situations. Understanding a conversation is necessary in order to response interactions that occurs with each other. Hutchby \& Wooffitt (Rezvani \& Sayyadi, 2015) stated that conversations in real life are organized to achieve the goals that can be understood by each other. Yule (Rezvani, \&Sayyadi, 2015) stated that the ability to ask questions not only allows students to create structured and natural conversations.

Asking a question requires good communication skills so that the message or the questions can be understood as well, and the elements required in asking a question are the mastery of good grammar, that of the material, and communicative skills. High school students with their capacity can ask a question properly because they already have high thinking level. Thomas \& Thorne (2010) suggested "Higher order thinking Occurs when a person takes new information and information stored in memory and interrelates and / or rearranges and extends this information to achieve a purpose or find possible answers in perplexing situations". Stimuli given to students to ask a question are highly important because the stimuli can motivate students to be curious about something. Hendriana (2012) suggested that a question is any sentence that has interrogative form or function. The purpose of asking questions is as follow: (1) To develop interest and motivation; (2) To evaluate preparation; (3) To develop thinking skills; (4) To foster insight; (5) To assess achievement of objectives; (6) To enhance knowledge.

Students' success in learning mathematics is not only seen by their work on problems or tests given. The ability to ask helps them uncover what has been learned so it can comprehensively explore their ability in posing questions. This is in line with the opinion of Tofade, Elsner \& Haines (2013) who suggested that questions initiated by students can improve high level learning because the questions require them to analyze, connect and illustrate information. A question can be classified good or less good. Less good Questions can make learning process to be not conducive and create confusion.

The ability to ask good question covers aspects of quality, language, relevance and frequency. This is in line with Widodo (Hendriana, Rohaeti \& Hidayat, 2016) who suggested that about half questions posed by teachers regarding with the material are mostly closed-ended questions that require short answers and are in the forms of memorization and understanding.

Understanding a mathematical problem must be significant to enable students to express meaningful statements based on the data, warranties, ideas, ideas that can generate good solutions. Elder \& Paul (2002) stated that thinking without statement is not an intellectual one. When facing complex problems, students often have difficulties in finding solutions because the problems are not routinely found by students. Piatek-Jimenez (2010) suggested that students often have difficulties in interpreting and proving a statement.

The quality of mathematical learning is dependent on how students understand the problems and solve them using innovative solutions. Zhang, Wang \& Li (2012) suggested in their study that students' ability is not only seen from their grade school, but also from how they are taught to make solution they can understand so it becomes an innovative one.

Hendriana (2012) stated that, in the learning process, students simply model and record how to resolve an exercise item that has been done by teachers. If this happens continuously, 
students will not get completion as expected. Minarni, Napitupulu \& Husein (2016) explained that students' mathematical representation and understanding ability is still relatively low. The study by Hendriana, Rohaeti \& Hidayat (2016) suggested that this lack ability is caused by the fact that the students are rarely given the opportunity to think openly due to the fact that they rarely ask questions of the problems being faced.

Students' ability to pose mathematical questions is always based on cognitive ability. Rahman (2013) argued in his research that students who have cognitive style of independent field are able to propose a mathematical problem which can be solved and load new data, with highquality math problem category. Students who have the cognitive style of field dependent are able to ask mathematical problems that can be solved but it does not contain new data with category of medium quality math problems.

The results of research by Hendriana (2013) about the communication skills in improving mathematics teachers' ability to pose questions in effect to the students' learning outcomes in elementary schools in Bandung shows that teachers who have communication skills in terms of asking that fall into the low category likely to result in student learning outcomes that is also low, while teachers communication skills in terms of asking who belong to good category tend to produce student learning outcomes that are classified as moderate and high.

Basically, both teachers and students already have the ability to ask, but it is not explored well yet. Therefore, motivating the students to develop mathematical questioning ability needs strategies that must be done by teachers by providing structured learning so that students can learn independently, at least in posing some problems encountered, both in the form of questions and statements. One of the strategies is to teach students to think metaphorically (metaphorical thinking).

Students' ability to ask questions is closely related to think metaphorically or clarify one's thinking. Meij \& Dillon (1994) argued that a question can be classified into necessary question and unnecessary questions. According to Holyoak \& Thagard (Hendriana, 2012), metaphor is originated from a concept known by students going to another concept that is unknown or is being learned. Metaphor is dependent upon a number of concepts and properties of objects being metaphorized.

Relations regarding to the development of the ability to ask and think metaphorically (metaphorical thinking) are: (1) students are able to connect the problems of a given statement into a question posed in order to dig deeper information, (2) the students are able to find new concepts that are not already known yet such as conjectures which are expected to become the basis of their question, (3) the students are able to create creative ideas coming from the problems faced, and (4) the students are able to apply the results of their thinking in the form of a question of a problem given statement.

In facing mathematics problems, it is expected that students are able to change the paradigm so it will be assumed that learning math is fun and easy. If previous learning only focused on cognitive aspects alone but must now be seen in other aspects as well. Besides, the phenomena on happening now is the relationship between real conditions that must be associated with mathematics in their daily lives; it certainly can be a very good reference, because math is not only counting or discovering formulas but also can be applied in their daily lives. Carreira (Hendriana, 2012) suggested that finding a link between mathematical and real phenomenon is a process and effort to play an important model. 
Metaphoric thinking in mathematics must be started by adding a model of the situation systematically, so that the models are interpreted from the viewpoint of semantics. Both teachers and students have the ability to ask questions, but it is not explored well yet. Developing the ability to ask in the subjects of mathematics requires strategies that must be done by teachers to support the learning process. One of them is by thinking metaphorically (metaphorical thinking). Metaphorical thinking is a process that uses metaphors to understand a concept. In line with Holyoak \& Thagrad (Hendriana, 2012), metaphor is originated from a concept known by student going to another concept that is unknown or is being learned. All this depends on the number and nature of the concept of object.

To clarify one's thinking of mathematical activity relationship can be track by metaphorical thinking. Hendriana (2012) described that the conceptual forms of metaphorical thinking include: (1) understanding of basic mathematical ideas, (2) building relations, (3) redefining.

The relationship between learning which teaches metaphorical thinking is the ability to connect problem from questions to become a referred statement to deeper information. Hendriana, Rohaeti \& Hidayat (2016) suggested that there are four links between the ability to ask and to think metaphorically, among which are: (1) students are able to connect the issue of the statement, (2) students are able to find a new concept that they have not known yet, (3) the students are able to create creative ideas derived from problems, (4) students are able to apply the results of their thinking into question.

In regards with the ability to ask and to think metaphorically in math, assessment needs to be done through further research on high school mathematics teachers' ability to ask in West Java province. The definition of the ability to ask in this study is the ability of teachers to connect, discover, create and apply the mathematical concept of statement to generate a problem in the form of the question in line with the concept.

Based on the background above, the problem and the purpose of this research is to investigate and examine: (1) whether the ability to ask of high school mathematics teacherswho obtain metaphorical thinking learning is better than those who obtain conventional usual learning. (2) whether there is an interaction effect between learning and KAM (Kemampuan Awal Matematis/Early Mathematics Ability) in developing the ability to ask of high school mathematics teachers. (3) How is the achievement of the ability to ask of high school mathematics teachers?

\section{METHOD}

This study is designed in the form of experimental with the design of only posttest control group whose purpose is to examine the role of learning that teaches metaphorical thinking towards the ability to ask of high school mathematics teachers. The population in this study is high school mathematics teachers in West Java province, while the sample is 124 high school teachers of mathematics courses who are set purposively and then determined randomly into the experimental class and control class. The tests of mathematical questioning proficiency in this study are compiled by referring to the characteristics of the ability to ask and guidelines of good test. Data is analyzed by using statistical tests of Two-Way Annova to see the differences and the effects of interaction between the learning and KAM in generating high school mathematics teachers' questioning ability. 


\section{RESULTS AND DISCUSSION}

Findings that are related to high school mathematics teachers' questioning abilityare presented in Table 1.

Table 1. Mathematical Questioning Ability

\begin{tabular}{ccccc}
\hline Prior Mathematical & \multicolumn{4}{c}{ Mathematical Questioning Ability } \\
\cline { 2 - 5 } Ability & \multicolumn{2}{c}{ MTClass $(\mathbf{n = 6 2})$} & Conventional Learning (n = 62) \\
\cline { 2 - 5 } & Mean & SD & Mean & SD \\
\hline Good & 8,64 & 1,07 & 8,16 & 1,22 \\
& $(86,40 \%)$ & & $(81,60 \%)$ & \\
Moderate & 6,83 & 0,78 & 6,37 & 1,06 \\
& $(6,83 \%)$ & & $(63,70 \%)$ & \\
Less & 6,21 & 1,10 & 5,76 & 0,86 \\
& $(62,10 \%)$ & & $(57,60 \%)$ & 1,14 \\
Total & 7,48 & 1,08 & 7,07 & $(70,70 \%)$ \\
& $(74,80 \%)$ & & & \\
\hline
\end{tabular}

Notes: ideal score is 10

Based on the results of the above description, interpretations obtained are as follows:

a) When viewed totally, the ability to ask of high school mathematics teachers who obtain metaphorical thinking learning is better than the conventional class. The teachers' ability to ask mathematical question teachers in both classes (conventional class and metaphorical thinking class) is still in high category (74.80\%> 70.70\% of the ideal score).

b) Based on the level of Early Mathematics Ability (KAM), the ability of mathematical questioning of teachers who acquire metaphorical thinking learning also looks different and shows that the ability of mathematical questioning of teachers who acquire metaphorical thinking learning is better than those in the conventional class. Mathematical questioning ability of good level on both class (MT and conventional) belongs to the high category $(86.40 \%>81.60 \%)$, while for medium level and less classified as moderate category $(68.30 \%>63.70 \%$ and $62.10 \%>47.60 \%)$.

c) In terms of factors which affect the development of mathematical questioning ability, then, based on the description in Table 1, it looks that both factors (both learning and KAM) affect the development of mathematical questioning. In addition, there is no interaction effect between learning and KAM jointly in developing teachers' ability in posing mathematical questioning.

To support the description of high school mathematics teachers' questioning ability above, then, data analysis of high school mathematics teachers' questioning ability is done through statistical tests of mean difference. After conducting normality test of the data distribution of high school mathematics teachers' questioning ability, then, it is found that the data normally distribute. Based on these findings, the test of ability mean difference above is done by using Two-Way Annova. (See Table 2)

Table 2. Summary of Two-Way Annova Test Development of Teachers' Mathematical Questioning Ability Based on the Factors of Learning and KAM

\begin{tabular}{lccccc}
\hline \multicolumn{1}{c}{ Sources } & JK & dk & RJK & F-test & Sig \\
\hline Learning Approach (A) & 17,808 & 1 & 17,808 & 17,020 & 0,000 \\
KAM (B) & 11,446 & 2 & 5,723 & 5,162 & 0,017 \\
A x B & 6,284 & 2 & 3,142 & 3,045 & 0,042 \\
Inter & 76,833 & 119 & 1,113 & & \\
\hline
\end{tabular}

(Taken from SPSS. 22 Output) 


\section{Learning Approach}

$\mathrm{H}_{0}: \mu_{e}=\mu_{k}$

$\mathrm{H}_{\mathrm{A}}: \mu_{e} \neq \mu_{k}$

Testing criteria: If $\operatorname{sig}>0,05$ then $\mathrm{H}_{0}$ is accepted

Based on Table 2, it is obtained that sig $=0,000$; or in other words sig $<0.05$. It can be concluded that, at the significance level of $5 \%$, there are significant differences between mathematical questioning ability of teachers whose learning use metaphorical thinking and those who use conventional class.

\section{KAM}

$\mathrm{H}_{0}: \mu_{b}=\mu_{s}=\mu_{k}$

$\mathrm{H}_{\mathrm{A}}$ : There is at least one KAM which differ significantly from the other KAM

Testing criteria: If sig> 0.05 then $\mathrm{H}_{0}$ is accepted

Based on Table 2 it was obtained that sig $=0,017$; or in other words sig $<0.05$; it can be concluded that, significance level of 5\%, at least there is one particular group of KAM whose mathematical questioning ability is significantly different from the other KAM. To find out which KAM that is significantly different, the Scheffe test is conducted. The results of the calculations are presented in Table 3.

Table 3. Scheffe test of Development of Mathematical Questioning Ability Based on KAM

\begin{tabular}{llccc}
\hline TKAS (I) & TKAS(J) & $\begin{array}{c}\text { Mean } \\
\text { Difference } \\
(\mathbf{I}-\mathbf{J})\end{array}$ & Sig & Interpretation \\
\hline Good & Moderate & 0,240 & 0,585 & Not different \\
Moderate & Moderate & 0,344 & 0,343 & Not different \\
Good & Low & $0,762^{*}$ & 0,037 & different \\
\hline
\end{tabular}

(Taken from SPSS.22 output)

According to Table 3 it is concluded that there are significant differences between the mathematical ability to ask at the KAM Good with low than the KAM Good and moderate with KAM moderate and low on the significance level of 5\%. The implication is that mathematical ability to ask of the teachers for KAM Good and Low is more developed than KAM Good and moderate with KAM moderate and low.

\section{Effect Interaction between Learning Approach and TKAS}

$\mathrm{H}_{0}$ : There is no interaction between the effects of approach and KAM

$\mathrm{H}_{\mathrm{A}}$ : At least there is one deviation that differs significantly from the others.

Based on Table 2 it was obtained that sig $=0.042$ is less than 0.05 ; it can be concluded that there is a significant interaction effect between learning approach (MT, and Basic) with KAM to produce teachers' mathematical ability to ask at the 5\% significance level.

Based on the findings in the field, the achievement of teachers' mathematical questioning ability has not been as expected. The achievement of the results is attached in Table 4. 
Table 4. Achievement of Mathematical Questioning Ability

\begin{tabular}{lccc}
\hline \multirow{2}{*}{$\begin{array}{c}\text { Indicators of } \\
\text { Mathematical Questioning Ability }\end{array}$} & KAM & $\begin{array}{c}\text { MT } \\
\text { Learning }\end{array}$ & $\begin{array}{c}\text { Conventional } \\
\text { Class }\end{array}$ \\
\hline \multirow{2}{*}{$\begin{array}{l}\text { Problems posed are connected with } \\
\text { statement contexts given }\end{array}$} & Good & $100 \%$ & $100 \%$ \\
\cline { 2 - 4 } & Moderate & $100 \%$ & $100 \%$ \\
\cline { 2 - 4 } & Low & $90 \%$ & $100 \%$ \\
\hline $\begin{array}{l}\text { Posing problems is in the form of } \\
\text { non-routine questions of given } \\
\text { statements }\end{array}$ & Total & $97 \%$ & $100 \%$ \\
\cline { 2 - 4 } & Good & $75 \%$ & $60 \%$ \\
\cline { 2 - 4 } $\begin{array}{l}\text { Posing problems is in the form of } \\
\text { open-ended questions of given } \\
\text { statements }\end{array}$ & Low & $67 \%$ & $53 \%$ \\
\cline { 2 - 4 } & Total & $68 \%$ & $52 \%$ \\
\hline & Good & $71 \%$ & $63 \%$ \\
\hline
\end{tabular}

The results, shown in Table 4, concludes that the achievement of mastery of mathematical ability to ask of high school teachers still has not been achieved well on indicators of problems in the form of a question submission of non-routine and open questions. Based on observation, the constraints faced by high school level mathematics teachers are difficult to make non-routine questions with open answers expect from students are as follow:

The atmosphere of learning in the classroom in applying the learning activities that leads students to think abstractly is caused by the initial conditions of students who are accustomed to only receive learning material without thinking of the material context in more depth.

1) Teachers' experience which make them not to keep up to date with the relevance of the times in the field of education, so in teaching, the teachers still use models, methods and strategies monotonous.

2) The demands of curriculum in realizing the learning outcomes in a learning atmosphere in accordance with the development of mathematical ability to ask because of the necessity of conformity plans and targets in implementing the curriculum.

3) Outputs of student learning outcomes are more quantity-oriented rather than quality in the form of understanding the subject matter.

Based on this, then we need learning innovation efforts which have the purpose of projecting the development of teachers and students' mathematical ability. These obstacles are in line with what Hendriana, Rohaeti \& Hidayat (2016) proposed that teachers still have difficulty in asking non-routine and open-ended questions at the problems of given statement.

\section{CONCLUSION}

Based on the results and discussion, it can be concluded that: (1) the ability to ask mathematical questions of high school teachers who obtain metaphorical thinking is better than those with conventional learning. Overall, the ability to ask mathematical questions of teachers with metaphorical thinking and conventional learning falls into the category of good. However, if the review is based on the ability of Early Mathematics (KAM), both classes which obtained metaphorical Thinking learning and conventional one at the good KAM fall into the category of high and KAM Moderate and low is classified as a category of moderate. (2) The factors of Learning and KAM affect the achievement of teachers' ability to ask mathematical questioning. In addition, there is the effect of the interaction between the 
learning and KAM together in developing high school mathematics teachers' ability to ask mathematical question. (3) Achievement mastery of the high school teachers' ability to ask mathematical questions still have not achieved well on indicators of problems in the form of a question submission of non-routine and open-ended questions. This makes the urgency of the problems that are treated with the existence of an undertaking in the form of innovative learning such as metaphorical Thinking that can be applied from elementary to secondary education. So, that both teachers and students will be accustomed to think more comprehensively from all directions of thought in solving problems of mathematics education.

\section{REFERENCES}

Elder, L., \& Paul, R. A. (2002). The Miniature Guide to the Art of Asking Essential Questions. Santa Rosa, CA: Fondation for Critical Thinking.

Hendriana, H. (2012). Pembelajaran Matematika Humanis dengan Metaphorical Thinking untuk Meningkatkan Kepercayaan Diri Siswa. Infinity, 1(1): 90-103.

Hendriana, H. (2013). Analisis Hasil Belajar Matematika Siswa SD Berdasarkan Kemampuan Komunikasi Guru dan Tingkat Kemampuan Awal Matematika Siswa. Seminar Nasional Matematika, Universitas Katholik Parahyangan. Bandung: Universitas Katholik Parahyangan.

Hendriana, H., Rohaeti, E. E., \& Hidayat, W. (2016). Junior High School Teachers' Mathematical Questioning Ability And Metaphorical Thinking Learning. Journal on Mathematics Education, 8(1), 55-64.

Meij, V. H., \& Dillon, J. T. (1994). Adaptive Student Questioning and Students' Verbal Ability. The Journal of Experimental Education, 62(4), 277-290.

Minarni, A., Napitupulu, E. E., \& Husein, R. (2016, January). Mathematical Understanding and Representation Ability of Public Junior High School in North Sumatra. Journal on Mathematics Education, 7(1), 45-58.

Piatek-Jimenez, K. (2010). Students' Interpretations of Mathematical Statements Involving Quantification. Mathematics Education Research Journal, 22(3), 41-56.

Rahman, A. (2013). Pengajuan Masalah Matematika di Tinjau dari Gaya Kognitif dan Kategori Informasi. Jurnal Ilmu Pendidikan, 19(2): 244-251.

Rezvani, R., \& Sayyadi, A. (2015). Instructors' and Learners' Questioning: A Case of EFL Classroom Discourse in Iran. Journal of Teaching Language Skills, 34(3), 141-164.

Thomas, A., \& Thorne, G. (2010). How to Increase Higher-Order Thinking. Center for Development and Learning Metairie, Louisiana.

Tofade, T., Elsner, J., \& Haines, S. T. (2013). Best Practice Strategies for Effective Use of Questions as a Teaching Tool. American Journal of Pharmaceutical Education, 77(7), 155.

Zhang, C., Wang, H., \& Li, W. (2012). The Research of the Relationship between University Mathematics Learning and Quality Education and Enforce of Human's Ability. Engineering Education and Management, 437-441. 